\title{
DISTANT THUNDER Credit where credit is due
}

\section{Geologist and science writer Nina Morgan applauds a remarkably frank revelation}

No doubt many of the early geologists received essential encouragement, inspiration and practical assistance from their wives, sisters and daughters. But generally they did not publicly acknowledge the help they received. However, one who did was the geologist John Phillips [1800-1874], the orphaned nephew of William Smith [1769-1839]. Smith paid for John's schooling and introduced him to the science of geology. In 1829, John, then working as the keeper of the Yorkshire Philosophical Society Museum, invited his sister Anne to join him in York. Neither married and the two lived together and supported each other emotionally, practically and intellectually for the next 33 years, until her death in 1862.

\section{Geological companion}

Almost from the moment they were reunited, Anne became involved in John's geological work, and letters to her from both John and William Smith suggest that she was very well educated, and very knowledgeable about geology. But the 'public debut' of her geological prowess came in 1842 when she discovered a vital piece of evidence about the origin of the Malverns.

In general terms, the Malvern Hills consist of a central Precambrian core of igneous intrusives bounded by a north-south trending fault, surrounded by Triassic sediments and marls on the east, and on the west by Cambrian and Silurian sediments, which lap unconformably onto the intrusives. In the 19th century the origin of the Malvern Hills was a hot-and very controversialtopic. On one side was Sir Roderick Murchison [1792-1871], who believed that the Malvern Ridge was intruded as a hot body after the Silurian sediments were laid down. On the other was Phillips, then working for the Geological Survey, who

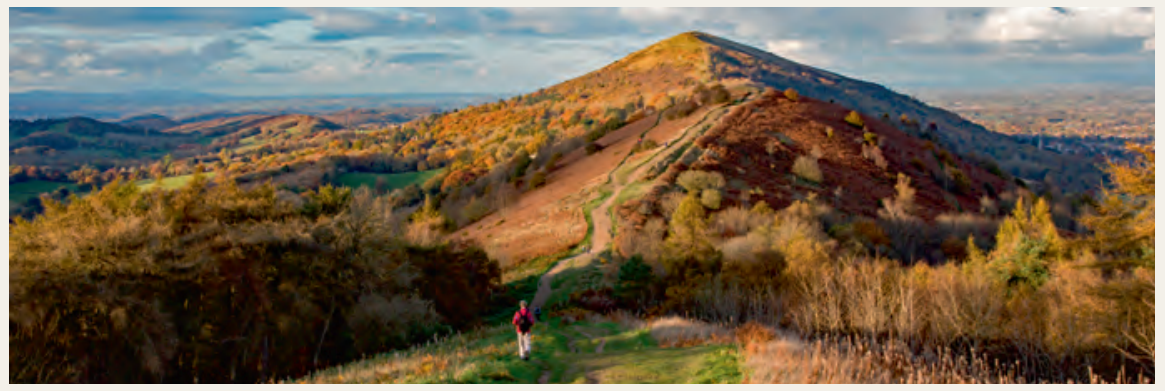

thought that the ridge was already elevated and cooled before the Silurian rocks were laid down. Phillips based his case on the fact that where the Silurian sediments are found in contact with the volcanics, they are not affected by metamorphism. He reasoned that as the Silurian seas lapped up against the ridge, fragments of the volcanics could have been eroded off and incorporated to form a conglomerate at the base of the Silurian. To clinch his argument, he needed to find the conglomerate.

\section{Miss Phillips's conglomerate}

On 1 August 1842, while Phillips was busy showing Murchison and other geologists around to explain his theories, Anne, who was staying with her brother in Malvern, went out in the field and found broken blocks of the conglomerate. Within a week she and John, accompanied by John's boss, Sir Henry De la Beche [1796-1855], managed to locate a place where the conglomerate was in contact with the intrusive.

Phillips quickly went into print with a report of the find in the October 1842 issue of the London, Edinburgh and Dublin Philosophical Magazine and Journal of Science. He described how, while he was in the field discussing the origin of the Malverns with other geologists:

"... My Sister, knowing the interest I felt in tracing out the history of the stratification visible in these trap [volcanic] hills, sought diligently for organic remains in the midst of and on the western flanks of the sienitic [syenitic] masses of the North hill and Sugar-loaf hill. In this most unpromising search she was entirely successful, and collected from the midst of heaps of fallen stones, which seemed to be all trap, several masses richly charged with organic remains, and full of feldspar, quartz, and hornblende, in grains and large lumps ....t was, in fact, certainly and evidently a conglomerate full of Silurian shells, and pebbles and fragments of the sienitic, felspatho- quartzose and other rockmasses of the Malvern hills." The rock became known as Miss Phillips's conglomerate-and samples of it soon became highly collectable items on geology field trips.

Phillips repeated this account, slightly abbreviated, in his 1848 Geological Survey Memoir. Considering that from its origin in 1835, the Geological Survey remained an all-male preserve until the early 20th century, that must have taken some doing!

End notes: References include: Morgan, N., Anne Phillips and the Mystery of the Malverns, Geoscientist, 16/7 2006; Morgan, N, 2007, Anne Phillips: John Phillips's Geological Companion, Geol. Soc. Spec. Pub. 281, pp 265 -275; Morrell, Jack, John Phillips and the Business of Victorian Science, ISBN 1840142391; and Phillips, J., 1848, Geol. Survey Memoir, Vol 2, Part 1, , pp. 66-67.

* Nina Morgan is a geologist and science writer based near Oxford. Her latest book, The Geology of Oxford Gravestones, is available via www.gravestonegeology.uk 